\title{
Infectivity of Potato Leaf-roll Virus in Salivary Secretions from Viruliferous Aphids
}

\author{
Satoshi TAnAKA* and Hiroyuki Shiota* \\ 田中 智*・塩田弘行*：ジャガイモ葉巻病ウイルス保毒アブラ \\ ムシの昍出物質中に利ける同ウイルスの活性
}

Ehrhardt et al. showed that a few virus-free aphids took up potato leaf-roll virus (PLRV) from an artificial diet when the viruliferous aphids fed on it ${ }^{1}$. In this paper the authors report the experimental results of the infectivity of virus in the salivary secretions from viruliferous aphids. A severe strain of PLRV used for the experiments was maintained on Datura stramonium plants in a greenhouse. The aphids used were apterous, adult green peach aphids (Myzus persicae Sulz.), and stock colonies of virus-free aphids were reared on Chinese cabbage or turnip plants. Viruliferous aphids were obtained by feeding on diseased D. stramonium for 2-4 days. Physalis floridana seedlings were used as test plants.

\section{Infectivity of the virus secreted into sucrose solution}

The infectivity of the virus in sucrose solution (7.5-15\%) on which viruliferous aphids were fed through parafilm membranes, was assayed by means of the aphid-injection method 2 . Feeding cages were made of cylindric plastic tubes $(3 \mathrm{~cm}$ in diameter). The tubes were cut off to a length of $2-3$ $\mathrm{cm}$ and the top ends were covered with stretched parafilm membranes. The volume of sucrose solution at $0.5-1 \mathrm{~m} l$ was placed on the membrane and covered with another thin membrane of parafilm. Groups of 20-60 viruliferous aphids were placed in these cages and then the bottom ends were covered with nylon nets. These cages were placed under artificial light at $20 \mathrm{C}$ for 2 days. The sucrose solution after feeding was injected into virus-free aphids. The injected aphids were reared on test plants, 5 aphids per plant for 3-4 days, and they were killed by spraying insecticides after inoculation feeding. The results showed that 3 of 67 test plants were infected by the injected aphids.

Two types of secretions were observed in the saliva secreted by an aphid; gelling (sheath) and

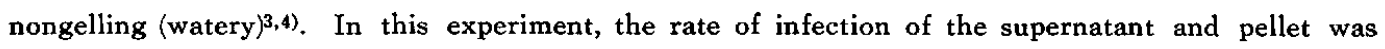
9.7 and $4.8 \%$, respectively, when the sucrose solution was centrifuged for $10 \mathrm{~min}$. at $4,000 \mathrm{rpm}$ after feeding. The infectivity of the supernatant was higher than that of the pellet. Howver, it is considered that further investigation is necessary to know the relationship between secreted saliva and virus.

Effect of dilution on the infectivity of PLRV in sucrose solution (salivary secretions) was tested by diluting the solution with a phosphate buffer solution $(0.01 M, \mathrm{pH} 7.2)$. The diluted solutions were tested for infectivity by injecting them into virus-free aphids. The results are shown in Table 1. The dilution end point was between 10 and 100 . When a group of 50 viruliferous aphids was macerated adding a $0.5 \mathrm{~m} l$ phosphate buffer solution, the macerate was diluted, the dilution end

* Hokkaido Chuo Potato Foundation Stock Seed Farm, Hiroshima, Hokkaido, Japan

1) Ehrhardt. P. and Schmutterer, H. (1965). Z. PflKrankh. PflPath. PflSchuts. 75 : 272-276.

2) Murayama, D. and Kojima, M. (1965). Ann. Phytopath. Soc. Japan 30: 209-215.

3) Miles, P. W. (1959). Nature 183: 756.

4) MacLean, D. L. and Kinsey, M. G. (1965). Nature 205: 1130-1131.

5) Arai, K., Doi, Y., Yora, K. and Asuyama, H. (1969). Ann. Phytopath. Soc. Japan 35: 10-15. 
Table 1. Effect of dilution on the infectivity of PLRV in salivary secretions and aphid macerates

\begin{tabular}{|c|c|c|}
\hline Dilution & Salivary secretions & Aphid macerates \\
\hline 1 & $2 / 40^{a)}(5.0)$ & $10 / 40(25.0)$ \\
\hline 10 & $1 / 20 \quad(5.0)$ & $2 / 48(4.2)$ \\
\hline 100 & $0 / 20 \quad(0)$ & $1 / 48(2.1)$ \\
\hline 1,000 & & $0 / 24(0)$ \\
\hline
\end{tabular}

a) Number of infected plants/Number of inoculated $P$. floridana plants, () : Percentage of infection

Table 2. Transmission of PLRV by needle-prick and aphid-injection methods with salivary secretions and aphid macerates

\begin{tabular}{lccccc}
\hline \multicolumn{1}{c}{ Methods } & Needle-prick & & Aphid-injection \\
& Crude juice & $\begin{array}{c}\text { Partially } \\
\text { purified juice }\end{array}$ & & Crude juice & $\begin{array}{c}\text { Partially } \\
\text { purified juice }\end{array}$ \\
Salivary secretions & $0 / 35$ & $1 / 35$ & & $0 / 20$ & $2 / 21$ \\
Aphid macerates & $0 / 35$ & $0 / 30$ & & $5 / 30$ & $7 / 21$ \\
\hline
\end{tabular}

Table 3. Infectivity of PLRV secreted from viruliferous aphids into plants

\begin{tabular}{lcccc} 
Transmission & \multicolumn{3}{c}{ Plant species } & \\
\cline { 2 - 5 } & D. stramonium & Potato & Turnip & Chinese cabbage \\
\hline No. of total tested plants & 118 & 91 & 170 & 56 \\
No. of infected plants & 1 & 3 & 4 & 0 \\
Percentage of infection & 0.8 & 3.3 & 2.4 & 0 \\
\hline
\end{tabular}

point was between 100 and 1,000 .

In 1969, Arai et al. succeeded for the first time in the mechanical transmission of PLRV by means of the needle-prick method using partially purified preparations from diseased plants to healthy test plants directly5). In this experiment, mechanical inoculation by means of the needle-prick method was carried out using crude and partially purified juices of the salivary secretions and aphid macerates. Partially purified preparations were made by two cycles of differential centrifugation $(8,000 \mathrm{rpm}$ for $30 \mathrm{~min}$. and $40,000 \mathrm{rpm}$ for $120 \mathrm{~min}$.) with the Hitachi $55-\mathrm{P}$ ultracentrifuge. The final supernatants were used as inoculum of the needle-prick method. The concentration of the supernatants was 10 times that of crude juice. The results are shown in Table 2. The test plants inoculated with crude juice of the salivary secretions were not infected, but 1 out of 35 test plants was infected with partially purified juice. On the other hand, the plants inoculated with crude and partially purified juice of the aphid macerates were not infected by the needle-prick method. The results of mechanical inoculation by the aphid-injection method are shown in Table 2. The infectivity of the partially purified preparations was slightly higher than that of crude juice in both preparations from salivary secretions and aphid macerates.

Infectivity of the virus secreted into plants

Fifty viruliferous aphids were reared for 2 days on leaf disks $(50-100 \mathrm{mg})$ of healthy potato (Danshaku), D. stramonium, turnip and Chinese cabbage plants. Then the disks were macerated ad- 
ding a $0.5 \mathrm{ml}$ phosphate buffer solution. The homogenates were centrifuged for $10 \mathrm{~min}$. at $4,000 \mathrm{rpm}$, and then the supernatants were injected into virus-free aphids to know about the infectivity. The results are shown in Table 3. The infectivity of virus secreted into host plants (potato and $D$. stramonium) was very low. The virus was recovered from turnip plants, but not Chinese cabbage plants, although both plants are immune to PLRV. The infectivity of the virus secreted in plant tissues was lower than that in a sucrose solution, and also the mortality of injected aphids was higher than that of the sucrose solution with saliva. From these results, it is considered that aphids are influenced by some plant substances introduced by injection.

The authors acknowledge the kind guidance and encouragement of Prof. D. Murayama, Faculty of Agriculture, Hokkaido University and wish to thank Dr. Y. Nishi, Kyushu Agricutural Experiment Station for his helpful suggestions on artificial feeding of aphids.

(Received September 12, 1972) 